\title{
Screening of Tyrosinase Inhibitor, Antioxidant and Cytotoxicity of Dried Sea Cucumber from Tomini Bay, Indonesia
}

\author{
Muhammad Nursid ${ }^{1, *}$, Endar Marraskuranto1, Azizah Kuswardini' ${ }^{2}$, Tjahyo Winanto²
}

\begin{abstract}
Background: Indonesia, as a tropical country, is one of the important producers of sea cucumbers (beche-de-mer). Sea cucumber is a marine invertebrate that contains attractive bioactive secondary metabolites and these metabolites can be used for health as well as cosmetics. Objective: The aim of the study was to determine the activity of tyrosinase inhibitors, antioxidants, and cytotoxicity of sea cucumber methanolic extract. Methods: Dried sea cucumber samples were taken from Boalemo waters, Tomini Bay, Indonesia. Tyrosinase inhibitor assay was carried out spectrophotometrically using tyrosinase enzymes and L-DOPA as a substrate and antioxidant tests were carried out by DPPH method. Cytotoxicity test against human breast cancer cell line (T47D) was conducted using the MTT assay. Results: The study showed that Bohadschia vitiensis had the best tyrosinase inhibitor activity with $\mathrm{IC}_{50}$ value of $0.28 \mathrm{mg} / \mathrm{ml}$. The DPPH free radical scavenging testing showed that all sea cucumbers had weak antioxidant activity. On the other hand, cytotoxicity assay revealed that several sea cucumbers had good cytotoxicity against T47D cells, where Holothuria atra and Bohadschia marmorata showed strong cytotoxicities with $\mathrm{IC}_{50}$ values of 23.0 and $28.1 \mathrm{ug} / \mathrm{mL}$, respectively Conclusion: Based on the study, it can be concluded that the dried sea cucumber from the Tomini bay region, Indonesia, has the potential to be developed as a source of tyrosinase inhibitors and cytotoxic agents.

Key words: Sea cucumber, Screening, Tyrosinase inhibitor, Antioxidant, Cytotoxicity.
\end{abstract}

\section{Muhammad Nursid ${ }^{1, *}$, Endar Marraskuranto ${ }^{1}$ Azizah Kuswardini², Tjahyo Winanto $^{2}$}

'Research Center for Marine and Fisheries Product Processing and Biotechnology, Ministry of Marine and Fisheries Affairs, INDONESIA.

${ }^{2}$ Faculty of Marine and Fisheries Science, University of Jenderal Soedirman, Purwokerto, INDONESIA

Correspondence

Dr. Muhammad Nursid

Research Center for Marine and Fisheries Product Processing and Biotechnology, Ministry of Marine and Fisheries Affairs, INDONESIA.

Phone no: +62-21-53650157

E-mail: muhammadnursid@gmail.com

History

- Submission Date: 06-11-2018;

- Review completed: 03-01-2019;

- Accepted Date: 20-01-2019

DOI : 10.5530/pj.2019.11.88

Article Available online

http://www.phcogj.com/v11/i3

Copyright

(c) 2019 Pharmacognosy Journal. This is an open-access article distributed under the terms of the Creative Commons Attribution 4.0 International license.

\section{INTRODUCTION}

Sea cucumber is a group of animals that lives in the sea. Sea cucumbers are usually soft-bodied echinoderms, looking like a cucumber, elongated, worm-like organisms, with a leathery skin and gelatinous body. ${ }^{1}$ They included in the Holothuroidae class and Echinodermata phylum. Sea cucumbers have long been fished and exported as dried. The dried form of sea cucumbers is called beche-de-mer in the Pacific and the Indian Ocean, balat in parts of Malaysia and the Philippines and in Indonesia popular as teripang. ${ }^{2}$ Sea cucumber has long been used by the people of Asia and the Middle East as food and traditional medicine. ${ }^{3}$ Teripang has a rich of nutrients, such as vitamin A, vitamin B1, vitamin B2, vitamin B3, and minerals, especially calcium, magnesium, iron, and zinc. It's also known to have broad spectrum of biological and pharmacological activity, such as anti-inflammatory i.e Holothuria edulis, cytoprotective i.e Holothuria atra, neuroprotective i.e Stichopus japonicus and cytotoxicity. ${ }^{4-8}$

Recently, research to explore marine bioactive compounds especially marine medicines and cosmetics shows increasing trend due to the diversity of the chemical structures and their bioactivities. ${ }^{9}$ In the

Cite this article: Nursid M, Marraskuranto E, Kuswardini A, Winanto T. Screening of Tyrosinase Inhibitor, Antioxidant and Cytotoxicity of Dried Sea Cucumber from Tomini Bay, Indonesia. Pharmacog J. 2019;11(3):555-8. 
oxidant activity, and cytotoxicity of dried sea cucumber extract taken from the waters around Tomini Bay, Sulawesi, Indonesia.

\section{MATERIALS AND METHODS}

\section{Samples Preparation and Extraction}

Dried sea cucumbers were collected from Tilamuta village, Boalemo District, Gorontalo-Indonesia. Samples used in this study were dried sea cucumbers that processed by a fisherman in the village. Sea cucumbers were taken from around waters of Tomini Bay. The samples obtained were identified based on Purcell ${ }^{16}$ and Setyastuti and Purwati. ${ }^{3}$ The extraction process was conducted by maceration using methanol for 12 h (3 times). The extract was filtered using filter paper and evaporated in vacuum rotavapor. The methanol was subsequently dried in vacuum concentrator until dry extract obtained.

\section{Tyrosinase Inhibitor Assay}

Tyrosinase inhibition assay was conducted according to Zamani et al. ${ }^{17}$ The sample was dissolved with DMSO as a stock solution. A range of extract concentration was prepared by dissolving concentrated extract using phosphate buffer ( $\mathrm{pH}$ 6.5). A total of $70 \mu \mathrm{L}$ of extract solution and $30 \mu \mathrm{L}$ tyrosinase enzyme (Sigma, 333 units of $\mathrm{mL}^{-1}$ in phosphate buffer solution) were put into 96-well plate and incubated for $5 \mathrm{~min}$. The mixture then was added with $110 \mu \mathrm{L}$ of substrate (L-DOPA $12 \mathrm{mM}$ ) and incubated at $37^{\circ} \mathrm{C}$ for $30 \mathrm{~min}$. The absorbance was measured at a wavelength of $492 \mathrm{~nm}$ using Microplate Reader. Kojic acid was used as a positive control. $\mathrm{IC}_{50}$ values were determined by using Minitab statistic package version 16.0.

\section{Antioxidant Assay}

The antioxidant assay was conducted according to Batubara et al. ${ }^{18}$ The dried extracts were dissolved in methanol and prepared in a range of concentrations as a sample solution. A total of $100 \mu \mathrm{L}$ of the sample solution and $100 \mu \mathrm{L}$ of $125 \mu \mathrm{M}$ DPPH solution were put into a 96-well plate. Samples were incubated at room temperature for $30 \mathrm{~min}$. After that, the absorbance was measured at a wavelength of $517 \mathrm{~nm}$ using a microplate reader. Ascorbic acid was used as positive control. Probit analysis to calculated $\mathrm{IC}_{50}$ value was carried out by using Minitab version 16.0.

\section{Cytotoxicity Assay}

Human breast ductal carcinoma cell line (T47D) was routinely grown and maintained in RPMI medium with $10 \%$ FBS and $1 \%$ penicillin-streptomycin. The cell line was incubated in a moisture-saturated atmosphere containing $5 \% \mathrm{CO}_{2}$ at $37^{\circ} \mathrm{C}$. Cytotoxicity test was conducted according to Nursid et al. ${ }^{19}$ To each well of the 96-well microplate containing 100 $\mu \mathrm{L}$ of cell suspension $\left(1.5 \times 10^{4}\right.$ cells $)$ was added $100 \mu \mathrm{L}$ of extracts with a concentration of $5,25,125$, and $625 \mu \mathrm{g} / \mathrm{ml}$ then the plate was incubated in a $\mathrm{CO}_{2}$ for $24 \mathrm{~h}$. After the addition of $100 \mu \mathrm{L}$ of 3-(4,5-dimethyl2-thiazolyl)-2,5-diphenyl-2H-tetrazolium bromide saline solution (0.5 $\mathrm{mg} / \mathrm{mL}$ ) to each well of a microplate, the plate was then incubated for 4 $h$ under the same conditions in the $\mathrm{CO}_{2}$ incubator. After incubation, the optical density was measured at $570 \mathrm{~nm}$ in a microplate reader (Thermo Scientific). Morphology cell was analyzed by using an inverted microscope. The $\mathrm{IC}_{50}$ values defined as the concentrations of a compound which inhibited $50 \%$ of the cell growth. $\mathrm{IC}_{50}$ value was determined by using Minitab probit analysis version 16.0.

\section{RESULTS}

In this study, 15 species of dried sea cucumbers were collected. After all samples were extracted with methanol, the extract was tested as a tyrosinase inhibitor, antioxidant, and cytotoxicity (Table 1).
Table 1: The activity of tyrosinase inhibitor, antioxidant, and cytotoxicity of sea cucumber methanolic extract

\begin{tabular}{ccccc}
\hline & & \multicolumn{3}{c}{ IC $_{50}$} \\
\cline { 3 - 5 } No & Species & $\begin{array}{c}\text { Tyrosinase } \\
\text { inhibitor } \\
(\mathbf{m g} / \mathrm{ml})\end{array}$ & $\begin{array}{c}\text { DPPH } \\
(\mathrm{mg} / \mathrm{ml})\end{array}$ & $\begin{array}{c}\text { Cytotoxicity } \\
(\mu \mathrm{g} / \mathrm{ml})\end{array}$ \\
\hline 1 & Actinopyga sp. & $\geq 500$ & 33.61 & 61.80 \\
2 & Bohadschia argus & 1.40 & $\geq 1,000$ & 142.0 \\
3 & Pearsonothuria graeffei & $\geq 500$ & 159,86 & 68.90 \\
4 & Holothuria atra & $\geq 500$ & 919.68 & 23.00 \\
5 & Holothuria edulis & $\geq 500$ & 1.78 & 54.21 \\
6 & Bohadschia ocellata & 31.12 & 15.64 & 56.70 \\
7 & Stichopus hermanii & 1.9 & $\geq 1,000$ & 341.20 \\
8 & Bohadschia marmorata & $\geq 500$ & 53.36 & 28.10 \\
9 & Holothuria impatiens & 174.49 & $\geq 1,000$ & 87.40 \\
10 & Actinopyga miliaris & $\geq 500$ & $\geq 1,000$ & 777.10 \\
11 & Holothuria sp. & 1.78 & 9.08 & 120.10 \\
12 & Bohadschia vitiensis & 0.26 & 7.19 & 74.70 \\
13 & Holothuria scabra & 34.29 & 4.17 & $>10,000$ \\
14 & Holothuria fuscogilva & 18.95 & $\geq 1,000$ & $>10,000$ \\
15 & Holothuria coluber & $\geq 500$ & 378.72 & 118.30 \\
16 & Kojic acid & 0.119 & - & - \\
17 & Ascorbic acid & & 0.00748 & - \\
18 & Doxorubicin & - & - & 0.1457 \\
\hline
\end{tabular}

The yield of sea cucumber extract ranged between 2.5-10.5\%. The result of inhibitor tyrosinase assay showed that Bohadschia vitiensis, $B$. argus, and Stichopus hermanii had the best activity with $\mathrm{IC}_{50}$ values of $0.28 ; 1.61$; and $1.65 \mathrm{mg} / \mathrm{mL}$. Antioxidant activity testing showed that the Holothuria edulis, H. scabra and B. vitiensis had the best activity with $\mathrm{IC}_{50}$ of $1.78 ; 4.1$; and $7.19 \mathrm{mg} / \mathrm{mL}$, respectively. While MTT test showed that Holothuria atra, and B. marmorata had the strongest cytotoxicity against T47D cells with $\mathrm{IC}_{50}$ values of 23.0 and $28.1 \mu \mathrm{g} / \mathrm{ml}$. Some species of sea cucumber i.e Holothuria edulis, Bohadschia ocellata, Pearsonothuria graeffei, and Bohadschia vitiensis have medium cytotoxicity with $\mathrm{IC}_{50}$ values ranging from $54.2-74.7 \mu \mathrm{g} / \mathrm{ml}$. Morphology features of the T47D cell after treated with $H$. atra and B. marmorata were described in Figure 1. Based on Figure 1, at a dose of $5 \mu \mathrm{g} / \mathrm{ml}$ cells morphology were still seen intact, it was similar with the untreated cell (cell control), but at doses of $25 \mu \mathrm{g} / \mathrm{ml}$ and $125 \mu \mathrm{g} / \mathrm{ml}$, the cells morphology changed to be unclear and the cell lost its integrity. Tyrosinase inhibitor profile, antioxidant activity, and cytotoxicity of various dried sea cucumber extracts were presented in Figure 2.

\section{DISCUSSION}

Brown skin on people in the tropics is often a concern in the field of beauty. Recently, many studies were conducted to explore materials or compounds that can act as a whitening agent. The brown color of the skin occurs due to excessive production of melanin. Melanin is responsible for human skin color. Tyrosinase is a metalloenzyme containing copper which is widely distributed in nature, including bacteria, fungi, plants, and animals. In mammals, tyrosinase plays a role in pigmentation of the skin, eyes, and hair. ${ }^{20}$

Tyrosinase is involved in the pigmentation process, by changing the L-tyrosine substrate to L-DOPA and converting the L-DOPA substrate 


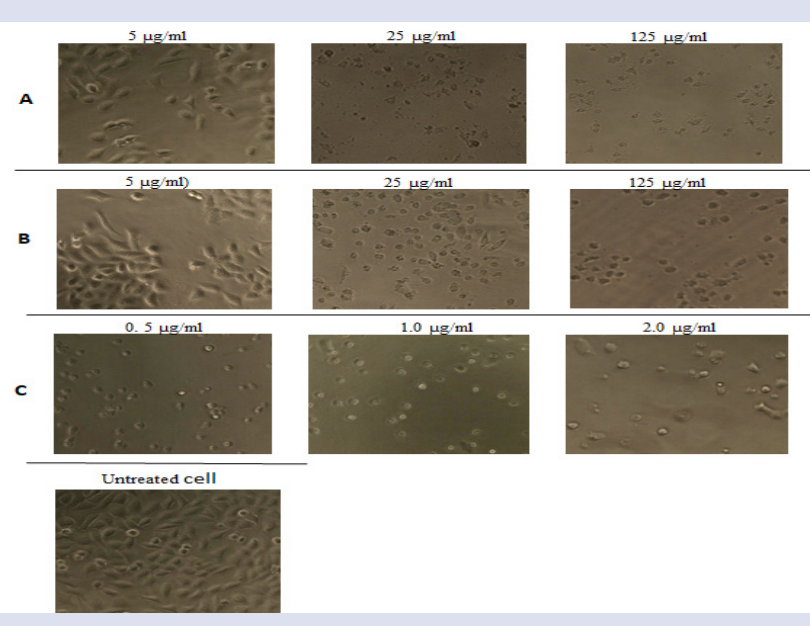

Figure 1: Morphology of T47D cell after treated 24 hours with methanolic extract of H. atra (A), B. marmorata (B) and doxorubicin as a positive control (C) compared with the untreated cell (magnification $40 \mathrm{x}$ )

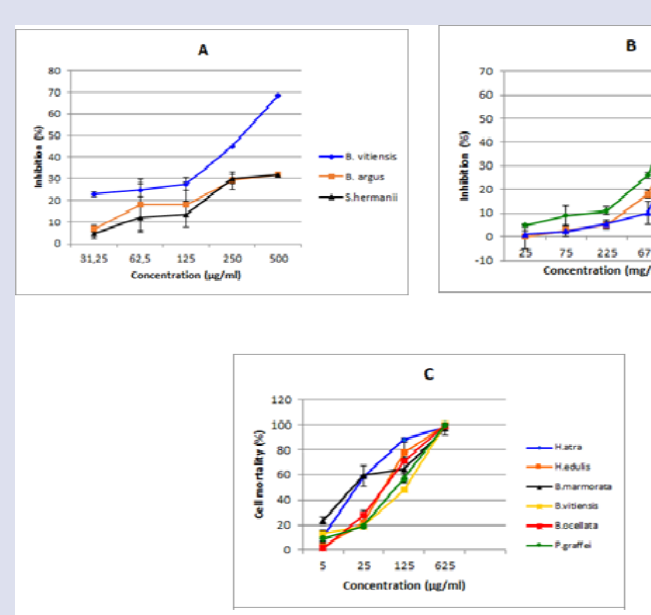

Figure 2: Profile of tyrosinase inhibitor (A), antioxidant activity (B), and cytotoxicity (C) of sea cucumber methanolic extract

to dopaquinone. The high reactivity of DOPA or dopaquinone causes polymerization reactions to form melanin (brown pigment). The mechanism of melanin formation through catalyzed tyrosine by tyrosinase enzyme to be 3,4-dihydroxyphenylalanine (DOPA), then DOPA is oxidized to dopaquinone and then reactions that produce eumelanin or pheomelanin pigments. ${ }^{21}$ Skin pigmentation can be reduced by inhibiting the activity of tyrosinase enzymes thereby inhibiting the reaction of L-tyrosine to L-DOPA or called inhibition of monophenolase and inhibiting the reaction of L-DOPA to dopaquinone or inhibition of diphenolase. In melanin formation reactions often produce reactive oxygen species (SOR) which can accelerate skin pigmentation. The enzyme tyrosinase and substrate reactions produce a brown color. Compounds that can inhibit the process of melanogenesis are expected to be applied in the cosmetic industry as whitening agents. Tyrosinase inhibitor makes melanin production reduced because the activity of this enzyme is the rate-controlling step of melanin synthesis. ${ }^{22}$ More specifically, tyrosinase inhibitors can be used in dermatological treatments for skin whitening by inhibiting the enzymatic process of melanin formation. ${ }^{20}$

Husni et al. ${ }^{23}$ found that sand sea cucumber extract can inhibit the activity of the tyrosinase enzyme, while Yoon et al. and Lee et al. states that sea cucumbers have the potential as inhibitors of melanogenesis. ${ }^{24,25}$ In this study, $B$. vitiensis had the best tyrosinase inhibitory activity with an $\mathrm{IC}_{50}$ value of $0.28 \mathrm{mg} / \mathrm{ml}$ even though the activity was not as good ascorbic acid $\left(\mathrm{IC}_{50}\right.$ of $\left.0.19 \mathrm{mg} / \mathrm{ml}\right)$. The antioxidant activity of $B$. vitiensis probably increases if the active compound is tested in the form fractions or a single compound. Possible compounds that have tyrosinase inhibitor activity from sea cucumbers are from phenolic compounds. ${ }^{12}$

Research to explore of active compounds from the sea other than as a whitening agent is also carried out to find compounds that can inhibit or neutralize free radicals. Reactive oxygen species (ROS) can cause damage to biomolecules such as proteins, fats, enzymes, DNA or RNA. Biomolecular damage due to ROS correlates strongly with the process of carcinogenesis, mutagenesis, and cancer occurrence. ${ }^{26,27}$ Sea cucumber extract activity related to antioxidant properties were revealed by Bandaranayake and Des Roches ${ }^{28}$ who found the activity of Holothuria atra as an ultraviolet protector. Ghanbari et al.$^{29}$ found that protein hydrolyzate from Actinopyga lecanora sea cucumber can inhibit DPPH and Ferrous ion-chelating (FIC) free radical. In addition, antioxidant properties of Sticophus japonicus was revealed by Wang et al..$^{30}$ In this study, the antioxidant activity of the sea cucumbers tested was included in the weak category in compare with an ascorbic acid activity which had an $\mathrm{IC}_{50}$ value of $0.00748 \mathrm{mg} / \mathrm{ml}$. Based on this, it can be said that the antioxidant activity of the dried sea cucumber methanol extract cannot be determined well by the DPPH method.

The results of the cytotoxicity test showed that more extracts had good activity in contrast with tyrosinase inhibitor and antioxidant tests. There were six sea cucumber extracts which have good cytotoxicity where the best potential was found in $H$. atra (Table 1 ). Many studies reported that the cytotoxicity of sea cucumbers is related to saponin (triterpenes glycosides) compounds found in sea cucumbers. Saponins in sea cucumbers have similar structures with saponins found in terrestrial plants, namely. ${ }^{4}$ These compounds were contained in the body wall and viscera. ${ }^{31}$

So far, approximately 150 types of saponins from the Holothuroidea sea cucumber have been identified. ${ }^{32}$ Some cytotoxic saponins from sea cucumbers that have been identified, for example, are frondoside, echinoside, holothurin, and philinopside, each of which was isolated from sea cucumber Cucumaria frondosa, Pearsonothuria graeffei, Holothuria vagabunda, and Pentacta quadrangularis. ${ }^{13,14}$ Cytotoxic compounds from sea cucumber $H$. atra, desulfated echinoside B (DEB), had $\mathrm{IC}_{50}$ values against A459 cells (human lung cancer cell line), HuH-7 (hepatocarcinoma cell line), HepG2 (liver cancer cell line), and B16F10 (murine melanoma cell line) with a range between $0.5-2.5 \mu \mathrm{M}$. Experimental and computational studies showed that DEB can act as an inhibitor of the PAK1 oncogenic kinase. ${ }^{15}$

\section{CONCLUSION}

Based on the screening inhibitor tyrosinase, antioxidant, and cytotoxicity activity, $B$. vitiensis showed the best tyrosinase inhibitor with $\mathrm{IC}_{50}$ value of $0.26 \mathrm{mg} / \mathrm{ml}$ while the antioxidant test showed weak activity against DPPH free radicals. Sea cucumber with the strongest cytotoxicity was shown by $H$. atra and B. marmorata with $\mathrm{IC}_{50}$ values of $23.0 \mu \mathrm{g} /$ $\mathrm{ml}$ and $28.1 \mu \mathrm{g} / \mathrm{ml}$.

\section{ACKNOWLEDGEMENT}

This research was supported by the Indonesia Research Center for Marine and Fisheries Product Processing and Biotechnology, Ministry 
of Marine Affairs and Fisheries, Indonesia. The authors would like to thanks to Diyah Ayu Hadiyati for helping in the assay, Ariyanti S. Dewi that contributed to improve this manuscript.

\section{CONFLICT OF INTEREST}

There are no conflicts of interest.

\section{ABBREVIATIONS}

DMSO: Dimethyl sulfoxide; L-DOPA: L-3,4-dihydroxyphenylalanine; DPPH: 2,2-diphenyl-1-picrylhydrazyl; MTT: 3-(4,5-dimethyl2-thiazolyl)-2,5-diphenyl-2H-tetrazolium bromide; T47D: Human breast ductal carcinoma cell; RPMI: Roswell park memorial institute medium; FBS: Fetal bovine serum.

\section{REFERENCES}

1. Janakiram NB, Mohammed A, Rao CV. Sea cucumbers metabolites as potent anti-cancer agents. Mar Drugs. 2015;13(5):2909-23. doi:10.3390/md13052909.

2. Akamine J. Conserving biodiversity for cultural diversity: A multi-sited ethnography of sea cucumber wars. Hatano: Tokai University Press. 2013;286.

3. Setyastuti A, Purwati P. Species list of Indonesian trepang. SPC Beche-de-mer Information Bulletin. 2015;35:19-25.

4. Bordbar S, Anwar F, Saari N. High-value components and bioactives from sea cucumber for functional foods-a review. Mar Drugs. 2011;9(10):1761-805 doi:10.3390/md9101761.

5. Wejisinghe WA, Jeon YJ, Ramasamy P, Wahid ME, Vairappan CS. Anticancer activity and mediation of apoptosis in human $\mathrm{HL}-60$ leukimia cells by edible sea cucumber (Hoolothuria edulis) exctract. Food Chem. 2013:139(1-4):326-31. Doi:10.1016/j.foodchem.2013.01.058

6. Nishikawa Y, Furukawa A, Shiga I, Muroi Y, Ishii T, Hongo Y, et al. Cytoprotective effects of lysophospholipids from sea cucumber Holothuria atra. PLoS ONE. 2015;10(8):e0135701. Doi: 10.1371/journal.pone.0135701.

7. Cui $C$, Cui N, Wang P, Song S, Liang H, Ji A. Nauroprotective effect of sulfated polysaccharide isolated from sea Cucumber Stichopus japonicus on 6-OHDA-induced death in SH-SY5Y through inhibition of MAPK and NF-kB and activation of PI3K/Akt signaling pathways. Biochem Biophys Res Commun. 2016:470(2):37583. Doi: 10.1016/j.bbrc.2016.01.035

8. Baharara J, Amini E, Nikdel N, Abdollahi FS. The cytotoxicity of dacarbazine potentiated by sea cucumber saponin in resistant B16F10 melanoma cells through apoptosis induction. Avicennia J Med Biotechnol. 2016;8(3):112-9.

9. Zhang J, Zhang H, Muehlmann LA, Jiang SC, Guo YW. Synthesis and structural modification of marine natural products. Molecules. 2017;22(6):882. doi:10.3390/molecules22060882.

10. Blunt JW, Copp BR, Keyzers RA, Munro MHG, Prinsep MR. Marine natural products. Nat Prod Rep. 2016;33:382-431. Doi: 10.1039/c5np00156k.

11. Imada C, Sugimoto Y, Makimura T, Kobayashi T, Hamada N, Watanabe E. Isolation and characterization of tyrosinase inhibitorproducing microorganisms from marine environment. Fish Science. 2001;67(6):1151-6.

12. Siahaan EA, Pangestuti R, Munandar H, Kim SK. Review cosmeceuticals properties of sea cucumbers: prospects and trends. Cosmetics. 2017;4(3):26. doi:10.3390/cosmetics4030026.

13. Khotimchenko Y. Pharmacological potential of sea cucumbers. Int J Mol Sci 2018;19(5):1342. doi:10.3390/ijms 19051342.

14. Attoub S, Arafat K, Khalaf T, Sulaiman S, Iratni R. Frondoside A enhances the anti-cancer effects of oxaliplatin and 5-fluorouracil on colon cancer cells. Nutrients. 2018;10(5):560. Doi:10.3390/nu10050560.

15. Shahinozzaman M, Ishii T, Takano R, Halim MA, Hossain MA, Tawata S. Cytotoxic desulfated saponin from Holothuria atra predicted to have high binding affinity to the oncogenic kinase PAK1: a combined in vitro and in silico study. Sci Pharm. 2018:86(3):32. doi:10.3390/scipharm86030032.

16. Purcell SW. Value, market preferences and trade of beche-de-mer from $\mathrm{Pa}$ cific Island sea cucumbers. PLoS ONE. 2014;9(4):e95075. Doi:10.1371/journal. pone.0095075

17. Zamani NP, Gazali M, Batubara I. The study of tyrosinase and antioxidant activity of Xylocarpus Granatum Koenig seed kernel extract toward evidence based indigenous knowledge from togean archipelago, Indonesia. J Marine Sci Res Dev. 2015;5(3):168. doi:10.4172/2155-9910.1000168.

18. Batubara I, Mitsunaga T, Ohashi H. Screening antiacne potency of Indonesian medical plants: antibacterial, lipase inhibition and antioxidant activities. J Wood Sci. 2009;55(3):230-5. Doi:10.1007/s10086-008-1021-1.

19. Nursid M, Namirah I, Cahyana AH, Fajarningsih ND, Chasanah E. Emestrin B: Epipolythiodioxypiperazine from marine derived fungus Emericella nidulans. Med Bioeng. 2015;4(6):441-4. Doi: 10.12720/jomb.4.6.441-445.

20. Chang TM. Tyrosinase and tyrosinase inhibitors. J Biocatal Biotransformation. 2012;1:2. Doi:10.4172/2324-9099.1000e106

21. Likhitwitayawuid K. Stilbenes with tyrosinase inhibitory activity. Current Science. 2008;94(1):44-52.

22. Yamaguchi K, Mitsunaga1 T, Batubara I. Isolation, Identification and Tyrosinase Inhibitory Activities of the Extractives from Allamanda cathartica. Natural Resources. 2011;2(03):167-72. doi:10.4236/nr.2011.23022

23. Husni A, Jeon JS, Um BH, Han NS, Chung, D. Tyrosinase inhibition by water and ethanol extracts of a far eastern sea cucumber Stichopus japonicus. J Sci Food Agric. 2011:91(9):1541-7. Doi:10.1002/jsfa.4335.

24. Yoon WJ, Kim MJ, Koh HB, Lee WJ, Lee NH, Hyun CG. Effect of Korean red sea cucumber (Stichopus japonicus) on melanogenic protein expression in murine B16 melanoma. International J Pharmacol. 2010;6(1):37-42. Doi:10.3923/ ijp. 210.37 .42

25. Lee TK, Kim SJ, Park SY, Hong SM, Kwon EH. Skin Whitening and Anti-Corrugation Activities of Glycoprotein Fractions from Liquid Extracts of Boiled Sea Cucumber. Asian Pacific Journal of Tropical Medicine. 2016;9(10):1002-6.

26. Vijayabaskar P, Shiyamala V. Antioxidant properties of seaweed polyphenol from Turbinaria ornata (Turner) J. Agardh, 1848. Asian Pac J Trop Med. 2012;S90-8.

27. Apak R, Gorinstein S, Böhm V, Schaich KM, Özyürek M, Güçlü K. Methods of measurement and evaluation of natural antioxidant capacity/activity (IUPAC Technical Report). Pure Appl Chem. 2013;85(5):957-98. Doi:10.1351/PAC REP-12-07-15.

28. Bandaranayake WM, Des Roches A. Role of secondary metabolites and pigments in the epidermal tissues, ripe ovaries, viscera, gut contents and diet of the sea cucumber Holothuria atra. Mar Biol. 1999;133(1):163-9.

29. Ghanbari R, Zarei M, Ebrahimpour A, Hamid AA, Ismail A, Saari N. Angiotensin-I converting enzyme (ACE) inhibitory and anti-oxidant activities of sea cucumber (Actinopyga lecanora) hydrolysates. Int J Mol Sci. 2015;16(12):28870-85. doi:10.3390/ijms161226140.

30. Wang J, Wang Y, Tang Q, Wang Y, Chang Y, Zhao Q, et al. Antioxidation activities of low-molecular-weight gelatin hydrolysate isolated from the sea cucumber Stichopus japonicus. J Ocean University of China. 2010;9(1):94-8.

31. Dyck SV, Gerbaux P, Flammang P. Qualitative and quantitative saponin contents in five sea cucumbers from the Indian Ocean. Mar Drugs. 2010;8(1):173-89. doi:10.3390/md8010173

32. Escandón MH, Espinosa RA, Marín FAS, Samyn Y. Biological and taxonomic perspective of triterpenoid glycosides of sea cucumbers of the family Holothuriidae (Echinodermata, Holothuroidea). Comp Biochem Physiol B Biochem Mol Biol. 2015;180:16-39. doi: 10.1016/j.cbpb.2014.09.007.

\section{GRAPHICAL ABSTRACT}

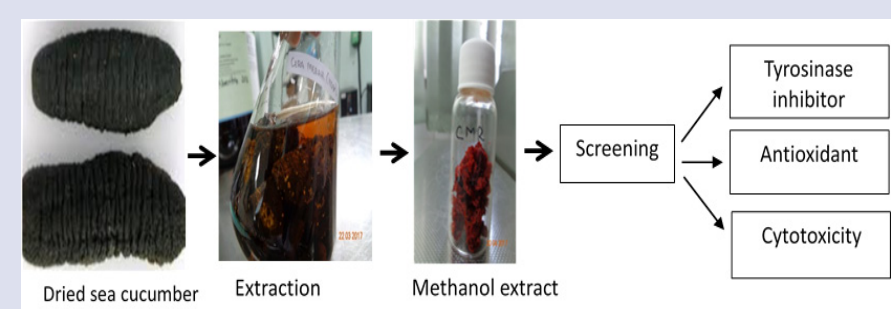

\section{SUMMARY}

- Methanol extract of dried sea cucumber from the Tomini Bay, Indonesia had been tested its activity as tyrosinase inhibitor, antioxidant and cytotoxicity. Bohadschia vitiensis had the best tyrosinase inhibitor activity with $\mathrm{IC}_{50}$ value of $0.28 \mathrm{mg} / \mathrm{ml}$. The DPPH free radical scavenging testing showed that all sea cucumbers had weak antioxidant activity. Cytotoxicity assay revealed that $\mathrm{Ho}$ lothuria atra and Bohadschia marmorata were the strongest cytotoxicities with $I_{50}$ values of 23.0 and $28.1 \mathrm{ug} / \mathrm{mL}$, respectively.

Cite this article: Nursid M, Marraskuranto E, Kuswardini A, WinantoT. Screening of Tyrosinase Inhibitor, Antioxidant and Cytotoxicity of Dried Sea Cucumber from Tomini Bay, Indonesia. Pharmacog J. 2019;11(3):555-8. 